\title{
Bilateral isolated lens coloboma associated with bicuspid aortic valve
}

\author{
Coloboma de cristalino bilateral isolado associado à valva aórtica bicúspide
}

Mustafa Dogan ${ }^{1}$, Onur Polat ${ }^{1}$, Onder Akcl ${ }^{2}$, Guliz Fatma Yavas $^{1}$, Umit Ubeyt Inan ${ }^{1}$

\begin{abstract}
A 27-year-old woman presented with a history of long-standing poor vision in both eyes. Ophthalmologic examination after pupillary dilatation revealed bilateral lens coloboma situated in the inferotemporal quadrant. No associated ocular abnormalities were seen, except amblyopia. A bicuspid aortic valve was observed during echocardiography during systemic evaluation. Lens coloboma usually occurs unilaterally; however, bilateral lens coloboma which is isolated or associated with other ocular malformations is also encountered. This is the first description of bilateral isolated lenticular coloboma associated with bicuspid aortic valve. Although the association between bicuspid aortic valve and lens coloboma may be an incidental finding, they may be components of an unknown syndrome.
\end{abstract}

Keywords: Coloboma; Aortic valve; Lens; Crystalline; Visual acuity; Humans

\section{RESUMO}

Uma mulher de 27 anos apresentou-se com uma história de longa data de deficiência visual em ambos os olhos. O exame oftalmológico após dilatação pupilar revelou coloboma de cristalino bilateral localizado no quadrante temporal inferior. Nenhuma outra alteração ocular associadas foi observada, exceto ambliopia. A valva aórtica bicúspide foi diagnosticada no exame de ecocardiograma durante a avaliação sistêmica. Coloboma cristaliniano ocorre geralmente de forma unilateral, no entanto já foi descrito bilateralmente, associado a outras malformações oculares ou isolado. Esta é a primeira descrição de coloboma cristaliniano isolado bilateral associado à valva aórtica bicúspide. Embora a associação de valva aórtica bicúspide e coloboma cristaliniano no nosso caso pode ter sido um achado incidental, eles podem ser componentes de uma síndrome desconhecida.

Descritores: Coloboma; Valva aórtica; Cristalino; Acuidade visual; Humanos

\section{INTRODUCTION}

Coloboma is an embryological eye abnormality caused by ocular developmental defects occurring during 5 th to 7 th weeks of gestation ${ }^{(1)}$. Lens coloboma is characterized by notching of the equator of the lens and is induced by regional defective or absent development of the zonules ${ }^{(2)}$.

Bicuspid aortic valve is an inheritable condition representing one of the most common cardiac anomalies. Although bicuspid aortic valve is commonly observed as an isolated finding, it may be associated with other cardiovascular anomalies such as aortic coarctation, Shone complex, Williams syndrome, patent ductus arteriosus, supravalvular/subvalvular aortic stenosis, Turner syndrome, and coronary artery anomalies ${ }^{(3)}$.

Several cases of sporadic unilateral or bilateral lens coloboma with and without systemic abnormalities have been described ${ }^{(4)}$. However, as far as we know, bilateral isolated lens coloboma associated with cardiovascular anomalies has not been reported before. Here, we report a case of bilateral isolated lens coloboma and associated bicuspid aortic valve.

\section{CASE REPORT}

A 27-year-old female was admitted to our clinic with a complaint of decreased vision since childhood. Uncorrected visual acuity was $1 / 10$ for both eyes. The best-corrected visual acuity was $2 / 10$ in the right eye with $-10.00 /-5.00 \times 165^{\circ}$ diopter correction and $3 / 10$ in the left eye with $-7.00 /-4.00 \times 10^{\circ}$ diopter correction. Ocular movements were normal. Intraocular pressure in both eyes as measured by Goldmann applanation tonometry was $14 \mathrm{mmHg}$. Anterior segment examination revealed a normal iris and no coloboma. After dilatation of the pupils, bilateral lens coloboma located in the inferior temporal regions was detected (Figure 1). Other ocular examinations, including fundus examination, fluorescein angiography, and optical coherence tomographic imaging revealed normal findings (Figure 2). Visual field testing using the 24-2 full-threshold strategy of the Humphrey Field Analyzer did not detect any defect. Medical and family histories were unremarkable. Because of the risk of an associated systemic disease, the patient was examined thoroughly by specialists in the departments of neurology, cardiology, internal medicine, and genetics. Neurology and internal medicine work-up did not reveal any abnormalities. Chromosomal analysis was normal, showing the 46 XX karyotype. In the cardiology work-up, echocardiography revealed a bicuspid aortic valve accompanied by an abnormal aorta (Figure 3). Coronary angiography or computerized tomographic angiography for imaging of other possible cardiac anomalies was not performed.

\section{DISCUSSION}

The eye develops from three embryological layers, including the neural ectoderm, neural crest, and the surface ectoderm. During the 4 th week of embryogenesis, the optic vesicle derived from the neural ectoderm invaginates and fuses through the lower nasal margin, leading to the formation of the optic cup. Any defects in the closure of fissures at this developmental stage leads to the occurrence of coloboma(1)

The etiopathogenesis of coloboma is heterogeneous. Although most frequently inherited as an autosomal dominant trait, autosomal recessive, X-linked, or sporadic cases can be observed. Furthermore, 


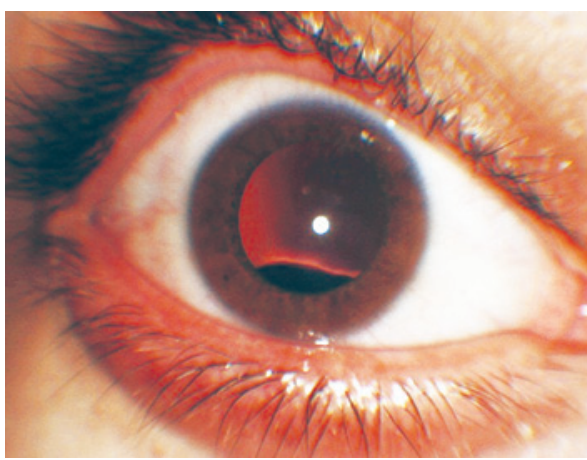

Figure 1. Lens coloboma, right eye (left), left eye (right).

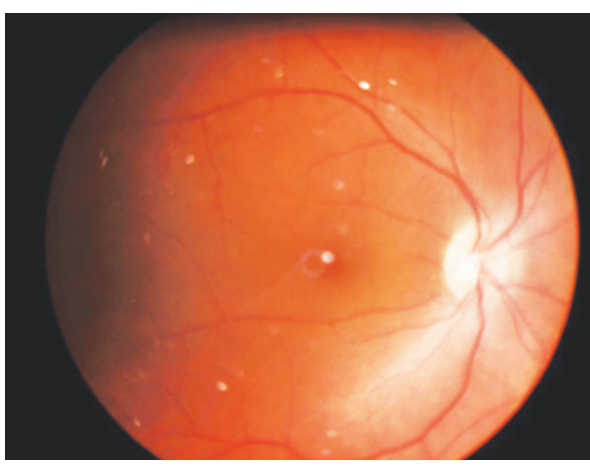

Figure 2. Normal fundus, right eye (left), left eye (right).
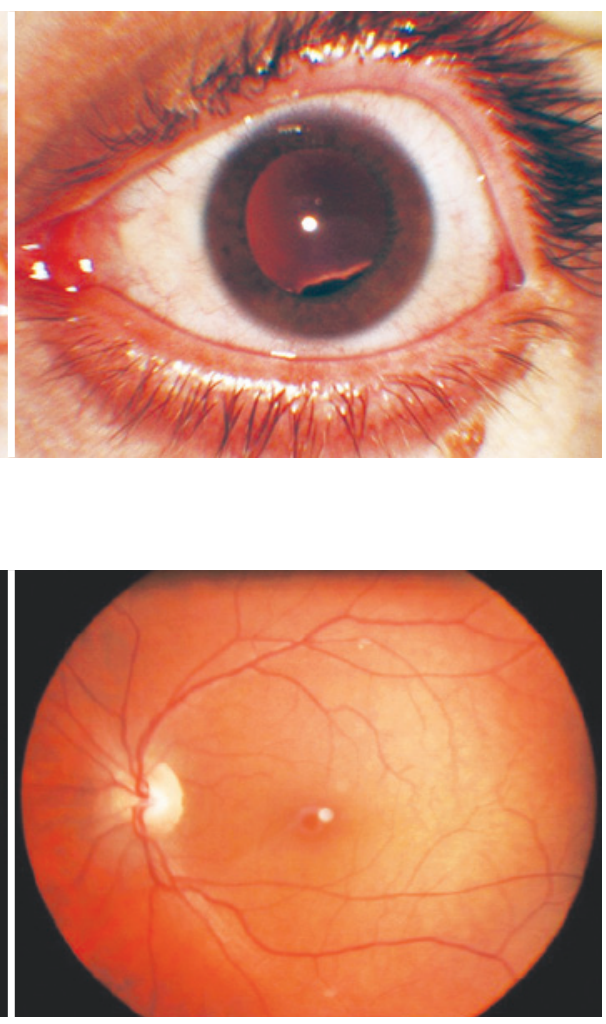

optic disc coloboma, or hypoplasia may be observed ${ }^{(6,7)}$. In our case, apart from a refractive error, we did not detect any other ocular abnormalities.

While lens coloboma may not be accompanied by systemic findings, some systemic disorders such as Marfan syndrome and Alport-like glomerulonephritis may be observed ${ }^{(8,9)}$. Bavbek et al. ${ }^{(2)}$ reported five cases of lens coloboma without any systemic disorders, three of which had bilateral lens coloboma. In addition, two cases with bilateral lens coloboma had no other ocular anomalies. Aggarwal et al.(4) reported craniofacial dysmorphism in one of two cases with isolated bilateral lens coloboma. As far as we know, isolated bilateral lens coloboma in the absence of other ocular anomalies have been reported only rarely, and the association with bicuspid aortic valve has not been previously reported, to the best of our knowledge.

The mechanisms underlying the development of bicuspid aortic valve are not clearly known. Other than being a simple anomaly of the fusion of the two valvular leaflets, it is suggested to be a disorder caused by complex developmental events. Because of association with other neural crest anomalies, it has been suggested that abnormal behavior of neural crest cells may lead to the formation of a bicuspid aortic valve. In addition, mutation in the notch1 gene, which encodes a class I transmembrane protein, functioning as a ligand-activated transcription factor and playing multiple roles in embryogenesis and self-renewing tissues of the adult organism, has been suggested to induce the bicuspid aortic valve; furthermore, abnormal fibrillin-1 and fibrillin microfibrillar proteins and deficient endothelial nitric oxide synthase have also been held responsible. The fibrillin-1 gene encodes a member of the fibrillin family. The encoded protein, Fibrillin-1, is a large, extracellular matrix glycoprotein that serves as a structural component of 10-12 nm calcium-binding microfibrils. These microfibrils provide force-bearing structural support in elastic and non-elastic connective tissue throughout the body. Mutations in this gene are associated with the Marfan syndrome, isolated ectopia 
lentis, autosomal dominant Weill-Marchesani syndrome, and Shprintzen-Goldberg craniosynostosis syndrome. Ocular findings such as hypertelorism, ptosis, strabismus, blue sclera, and cataract have been previously reported in bicuspid aortic valve cases, and bicuspid aortic valve in this case may be a minor expression of Marfan syndrome; however, as far as we know, our case is the first to be associated with bilateral lens coloboma ${ }^{(10)}$.

In conclusion, lens coloboma may present bilaterally as an isolated ocular finding, apart from being associated with other ocular anomalies. Both coloboma and bicuspid aortic valve may be observed in association with other congenital syndromes. Bicuspid aortic valve and lens coloboma presented in our case may be components of an unknown syndrome, which needs to be corroborated by additional studies.

\section{REFERENCES}

1. Onwochei BC, Simon JW, Bateman JB, Couture KC, Mir E. Ocular colobomata. Surv Ophthalmol. 2000;45(3):175-94.
2. Bavbek T, Ogut MS, Kazakoglu H. Congenital lens coloboma and associated pathologies. Doc Ophthalmol. 1993;83(4):313-22.

3. Siu SC, Silversides CK. Bicuspid aortic valve disease. J Am Coll Cardiol. 2010;55(25): 2789-800. Comment in: J Am Coll Cardiol. 2011;57(4):518; author reply 519; J Am Coll Cardiol. 2011;57(4):518-9; author reply 519.

4. Aggarwal A, El-Bash AR, Inker S, Musarella MA. Symmetrical bilateral lens colobomas in two brothers. J Pediatr Ophthalmol Strabismus. 2004;41(5):302-4.

5. Stoll C, Alembik Y, Dott B, Roth MP. Epidemiology of congenital eye malformations in 131,760 consecutive births. Ophthalmic Paediatr Genet. 1992;13(3):179-86.

6. Hovland KR, Schepens CL, Freeman HM. Developmental giant retinal tears associated with lens coloboma. Arch Ophthalmol. 1968;80(3):325-31.

7. Fard AK, Traboulsi El. Coloboma of the lens, optic nerve hypoplasia and orbital hemangioma-A possible developmental field defect. Ophthalmic Genet. 1998;19(4):209-12.

8. Mehrotra AS, Solanki N, Sabharwal KK. Bilateral coloboma of lens in Marfan's syndrome Indian J Ophthalmol. 1985;33(3):201-2.

9. Amari F, Segawa K, Ando F. Lens coloboma and Alport-like glomerulonephritis. Eur J Ophthalmol. 1994;4(3):181-3.

10. Fedak PW, Verma S, David TE, Leask RL, Weisel RD, Butany J. Clinical and pathophysiological implications of a bicuspid aortic valve. Circulation. 2002;106(8):900-4. Comment in: Circulation. 2003;107(16):e105; author reply e105.

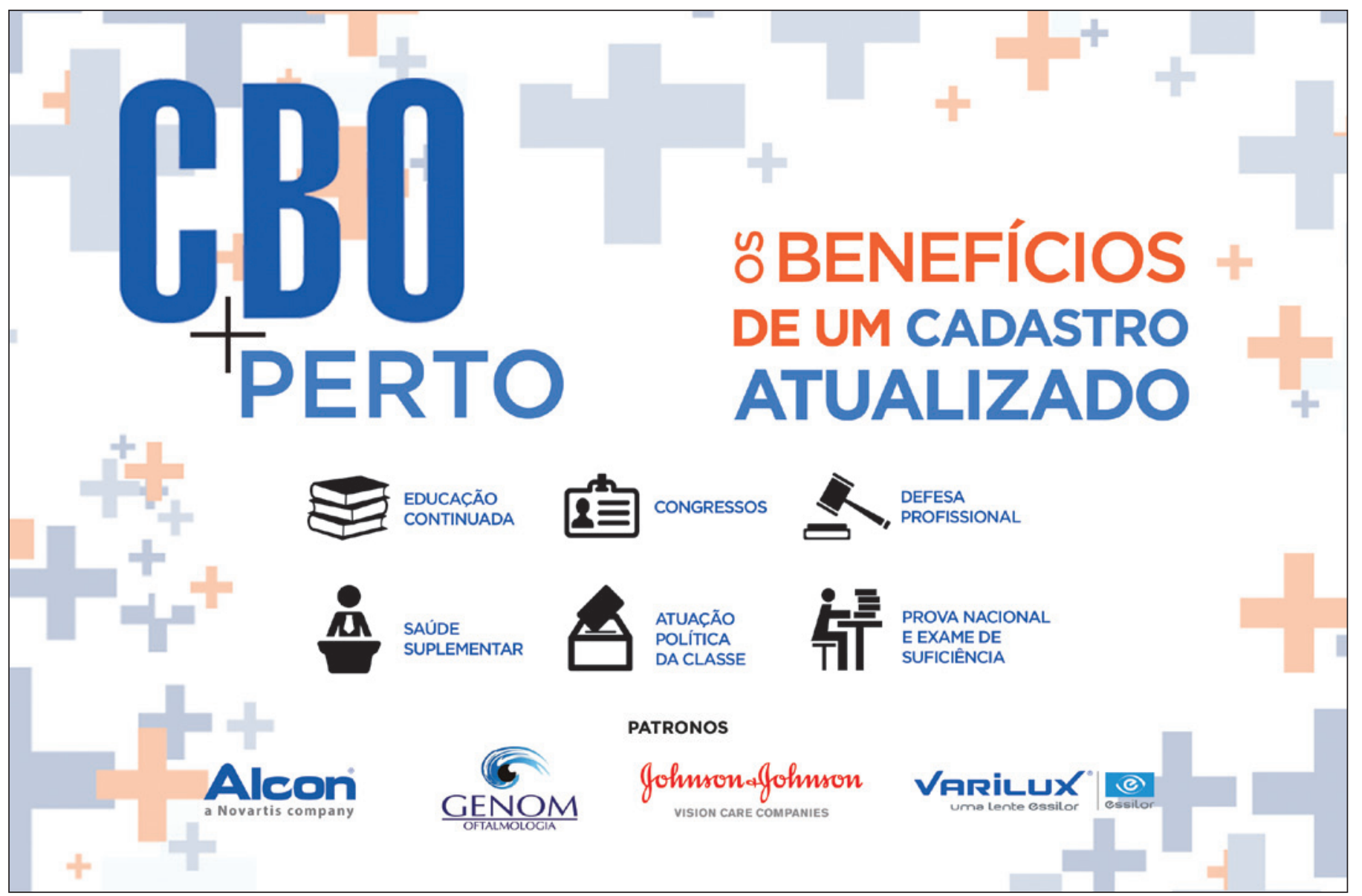

